\title{
Acceptance Programs for Parents with Down Syndrome Children
}

\author{
Syari Yuliana, Tjutju Soendari, Sunardi \\ Departement of Special Need \\ Universitas Pendidikan Indonesia \\ Bandung, Indonesia \\ syariyuliana12@student.upi.edu
}

\begin{abstract}
Parental acceptance problems of children with Down syndrome will have an impact on psychological, children's achievement in school, and children's independence. This study aims to formulate an acceptance program for parents who have children with Down syndrome. The research subjects were three parents who had children with Down syndrome. Observations, interviews and documentation are used to explore data relating to the objective conditions of parental acceptance and the efforts that have been made by schools to increase parental acceptance. The results of the data analysis showed that the acceptance of three parent subjects was still in the second phase stage where there were still feelings of contradiction, feeling guilty, angry, embarrassed and feeling humiliated, as well as confusion in caring for children. The acceptance program for parents who have Down syndrome children contains four aspects that are mixed from the factors that influence reception, namely: knowledge support, religious support, emotional support, and social support. Program suitability with parental needs and paying attention to the principle of flexibility will direct parents to accept the condition of their child who has down syndrome.
\end{abstract}

Keywords—parent acceptance; child down syndrome; program.

\section{INTRODUCTION}

Psychological or psychological problems, as well as confusion about appropriate interventions for children with Down syndrome, were often the difficulties experienced by parents who have children with the syndrome [1]. Research showed that the level of stress and depression of everyday parents was highest among other SSN parents, such as down syndrome, mental disorders, etc. [2]. Shock, stress, sadness, disappointment, refusing, ignoring, feeling guilty, anger were emotional reactions that parents display as psychological problems experienced. Emotional reactions were first displayed by parents when they learned their children were down syndrome, such as feelings of shock, inner shock, shock, and not believing in what was happening to their children [3]. As a result of these emotional reactions, the emotional condition of parents becomes less stable, and this also triggers quarrels and blaming between husbands and wives, parents-in-law and wives, in-laws and husbands, and so on. The dynamics of all family relationships have changed because they feel overwhelmed, concerns about family finances, mental fatigue, disruption of relationships with other family members [4]. Concerns often arise in parents due to several problems such as children's opportunities when facing future realities that will emerge later and confusion about appropriate treatment of children [3]. Acceptance of parents can be seen from the emergence of dimensions of warmth in the family. The dimension of warmth is related to the quality of the affective bond between parents and their children both physically, verbally and symbolically the behavior displayed by parents to express feelings that refer to warmth, affection, attention, comfort, maintenance, and support [5].

Down syndrome children really need support and acceptance, especially parents, to be able to manage emotions positively [6]. Individual emotional needs will be a positive response from the people they love [7]. Parents or families with Down syndrome children need emotional endurance and information on how to live peacefully with children with the syndrome [8]. Families with Down syndrome children need friends or integrated social and recreational support to respond to the needs of children with Down syndrome for socialization, love, and recognition of their identity [4]. In addition, they also need information and inspiration from families who have children with Down syndromes who has achievements [1] Clinical information about child disabilities, training related to skills development, and management of behavior are needed by parents to become "follow-through" teachers so that they can implement home-based learning plans [1]. Based on the description of the background it is necessary to formulate an acceptance program for parents who have children with Down syndrome so that the acceptance of parents who are getting better will have a positive impact on optimizing the potential and development of children with Down syndrome.

\section{METHOD}

This research is included in Research and Development ( $R$ $\&$ D) research using ADDIE (Analysis, Design, Development, Implementation, and Evaluation) designs. This research starts from January to June 2018. Located in SLB C Purnama Asih. The selection of research sites in the school because SLB C Purnama Asih is an extraordinary school that specifically accepts students who have intellectual development and down syndrome. Participants in this study were parents who had children with Down syndrome at C Purnama Asih SLB, whose acceptance categories were still classified as primary, secondary, and tertiary categories a, as well as principals and three teachers. The selection of the study participants used purposive sampling technique which was carried out by taking 
the subject not based on strata, random or regional, but on the basis of certain objectives chosen deliberately in accordance with the specific criteria set by the researcher [9], [10], [11]. Data collection techniques used in this study are observation, interviews, and documentation. This observation activity was carried out to find out the objective conditions of parents 'acceptance and parents' problems in accepting their child's condition. In addition, observation is also intended to find out the efforts that have been done by the school to help parents in accepting the condition of children with Down syndrome. Indepth interviews were conducted with parents who had children with Down syndrome to find out more about their parents' acceptance of their children, as well as the level of parental acceptance of their children. While the interview with the teacher is done to explore more about the efforts that have been done by the school to help parents whose conditions of acceptance for children with special needs have not been optimal, as well as the teacher's response to the acceptance program that has been implemented. The documentation carried out in this study is to find out documents/records of the development of Down syndrome, including written documents related to the efforts that have been made by the school.

\section{RESULT AND DISCUSSION}

The objective condition of the acceptance of parents of Down syndrome children was still in the second phase which is marked by the appearance of conflicting feelings, such as on one side, the mother has affection for her child but on the other hand there was still hatred towards her child; angry reactions caused by confusion in caring for children, parents cannot control their emotions so angry reactions were more often raised; shy reactions and feeling guilty also often occur in parents who have children with Down syndrome. These problems make parents' acceptance of their children with Down syndrome progressively diminish and sometimes become worse and worst until they no longer send their children to school. This indicates a decline from the acceptance of parents to their children. When viewed from the problems experienced by these three parents, the parent's acceptance is at the second phase, namely the presence of ambivalence, guilt, anger, shame \& embarrassment. Ambivalence was often experiencing conflicting feelings, for example, sometimes angry at the condition of the child but on the one hand feel sorry, on the other hand, there is a sense of confusion and resignation. Then it is also marked by feelings of guilt, which is feeling guilty about the disability of his child so that thought arises. Sometimes parents become obsessive and emotional and periodically ask why this is happening. Anger also often occurs for parents whose acceptance is in this phase. Usually appears angry with oneself, then angry at what the doctor, therapist, spouse or other biological child said. Shame and embarrassment, these feeling arises when the mother faces a social environment that refused, pity, or mocks child disability. Continuous environmental attitudes like this can reduce selfesteem because some mothers consider children to be their successors. The presence of a disabled child can threaten his pride.

The school principals and teachers also feel parental anxiety. They also feel that from day to day the parents' acceptance of their children decreases. There were even some children who quit school because of the divorce of their parents. On the other hand, teachers also often complain about the parental treatment of children with Down syndrome. The teacher has seen parents who scold their children because their children cannot put up shoes. Even though his son's motoric was not able to put on his shoes because he was rarely trained. Teachers often feel annoyed, when parents were asked to cooperate in terms of training children's independence. The teacher has tried to tell parents that whatever activities are taught at school, please repeat them at home. Because the time for children in school is not long, much longer time for children with parents at home. But there were still many parents who do not understand this. Parents sometimes do not realize, that to train some activities for children with Down syndrome was not easy. It took time, needs patience, and consistency. Therefore, a collaboration between the school and parents has not been established. The school has made several efforts to increase parental acceptance, such as giving advice and motivating parents from face to face. Although not all teachers have done this. Schools also make home visits if there were children who have not been to school for a long time. These efforts have not been routinely implemented.

The acceptance program for parents who have children with Down syndrome is a systematic sequence of commands that is stored in one file so as to produce the desired results with a continuous implementation involving parents who have children with Down syndrome with acceptance that were still in the second phase. However, this program does not mean that it can only be applied by parents in the second phase only, for parents whose acceptance is in the primary phase can also use this program. There are several variations and additions to the material and its activities, while for its own aspects it remains the same as involving four aspects of knowledge, emotion, religion, and social.

This program was a development program for parents with Down syndrome children who aimed to optimize and increase their acceptance towards their children so that it will directly affect the development of children with Down syndrome to a more positive direction. This program will be contained parent activities coordinated and accommodated by schools specifically for parents who have children with the syndrome. The program with four themes contains interrelated activities starting from activities with the theme of knowledge support, which aims to strengthen the understanding and knowledge of parents regarding the special needs of children with Down syndrome. Then it will be continued with other activities themed religious support, emotional support, and social support. This research and development resulted in an acceptance program for parents who had children with Down syndrome. Based on the results of the study and discussion can be concluded that the development of the acceptance program for parents who have Down syndrome children was developed with the ADDIE development research approach including five stages, namely Analysis, Design, Development, Implementation, and Evaluation. The quality of the program produced after going through conceptual testing (validation by experts) and implementation are as follows. 
Judging from the readability aspect, the language used in the program is easy to understand, the explanation described in each aspect of the program is detailed and operational. From the aspect of meaningfulness, the acceptance program that has been prepared is able to be a guide for parents to be able to accept the child's condition both in the primary and secondary phases and to be an implementation guide for the school. Judging from the aspect of usefulness, the acceptance program that has been made can provide support from knowledge, emotion, social and religion so that parents can change the condition of dis-acceptance to accept the condition of their children. This acceptance program for parents who have children with the syndrome in SLB Purnama Asih is the right activity to be able to optimize the acceptance of parents and provide support for parents so they can create a dimension of warmth in the family. From the aspect of achieving the purposes, the goals set in the program are in accordance with the needs of parents to reach the acceptance stage, and the goals set in the program are in line with school expectations. Judging from the aspect of the suitability of the program content, the aspects listed in the program have represented parental needs related to optimizing parental acceptance and the order in which the program is made in accordance with the conditions and needs of parents to increase their acceptance of children with Down syndrome.

When a family has a child with Down syndrome, two attitudes will appear, accepting the condition of the child or refusing. As expressed by [12] there are two possible attitudes that will be raised by family members to individuals who are mentally retarded, accepting or refusing. Correspondingly, according to [13] having children with Down syndrome was a heavy burden for parents both physically and mentally. From the results of interviews and observations that have been made to these three subjects, it appeared that they have not been able to accept the condition of their children, even though they stated that they accept the child, the attitudes and treatment they bring to their children were not in accordance with the theory expressed by [5]. He states that parental acceptance leads to warmth, affection, caring, comfort, attention, nurturing, supporting, or a feeling of love where parents can feel and show their children physically and verbally. Since having children with Down syndrome, they feel they have little time, were tired of having to take their children to seek treatment, a lot of money used, and worry about the future of their children when they are unable to care for their children anymore. This is in line with what was stated by [14] that parents with disabled children naturally experience stress in various aspects of the family such as the demands for daily care, emotional distress, interpersonal difficulties, financial problems and adverse social consequences such as being ostracized by the community.

The reaction or response phase of the acceptance was still in the second phase where there was still ambivalence, guilt, anger, shame \& embarrassment. This is in accordance with [15] and [16] that parental acceptance can be said to be in the second phase if there is a feeling of ambivalence, often experiencing conflicting feelings, guilt, anger, shame, and embarrassment (humiliation). Correspondingly, Somantri revealed that children with Down syndrome cause an impact on parents such as guilt, sin, lack of confidence, surprise/disbelief, shame, and overprotective [17]. This is supported by the results of Hamid's study [18], which showed that parents who have Down syndrome children experience feelings of sadness, refusing, depression, shame, and anger to accept their child's condition. From this case, it can be analyzed that there was a problem that kept the parents still stagnant in the second phase. Whereas three other parents who also had Down syndrome children had reached the tertiary phase where they had reached the acceptance stage. A research evidence showed that emotional neglect by parents towards their children will be a significant risk factor for cerebral infarction in the elderly [19]. In addition, rejection felt by children which cause long-term emotional trauma [20]. This effect will cause neurobiological and neuropsychological changes that can ultimately endanger the child's central nervous system and psychosocial development [21]. Besides the psychological adjustment problem, rejection or neglect also causes mental health problems such as depression; behavioral problems, including behavioral disorders, externalizing behavior, and delinquency; substance abuse [22] from the analysis phase of the acceptance condition so that parents who have Down syndrome children can accept their child's condition and have a number of competencies, of course, parents must obtain access to sufficient information and knowledge. Knowledge for parents can be obtained through various ways such as seminars, workshops, meeting forums, groups, and internet access. Therefore, an acceptance program is mapped or designed that fits and suits the needs of parents.

\section{CONCLUSION}

The acceptance program for parents who have Down syndrome children contains four aspects that were mixed from the factors that influence reception, namely: knowledge support, religious support, emotional support, and social support. Program suitability with parental needs and paying attention to the principle of flexibility will direct parents to accept the condition of their child who has down syndrome.

\section{REFERENCES}

[1] M. R. Gargiulo, Special Education in Contemporary Society, USA: Sage Publication Inc, 2014.

[2] M. J. Baker-Ericzén, L. Brookman-Frazee, and A. Stahmer, "Stress Levels and Adaptability in Parents of Toddlers with and without Autism Spectrum Disorders," Research and Practice for Persons with Severe Disabilities, vol. 30, no. 4, pp. 194-204, Dec. 2005.

[3] F. Mangunsong, Psikologi dan Pendidikan Anak Luar Biasa Jilid 1, Jakarta: LPSP3, 2011.

[4] R. M. Gargiulo, Working with parents of exceptional children: A guide for professionals, Houghton Mifflin School, 1985.

[5] R. P. Rohner, A. Khaleque, and D. E. Cournoyer, "Parental AcceptanceRejection: Theory, Methods, Cross-Cultural Evidence, and Implications," Ethos, vol. 33, no. 3, pp. 299-334, Sep. 2005.

[6] J.W. Santrock, Adolescence, Jakarta: Erlangga, 2011.

[7] R. P. Rohner, "The Parental 'Acceptance-Rejection Syndrome': Universal Correlates of Perceived Rejection.," American Psychologist, vol. 59, no. 8, pp. 830-840, Nov. 2004.

[8] R. Gargiulo, and Kilgo, J. An introduction to young children with special needs: Birth through age eight, Nelson Education, 2013.

[9] S. Arikunto, Metode penelitian kualitatif, Jakarta: Bumi Aksara, 2006. 
[10] S. Sugiyono. Metode penelitian kuantitatif, kualitatif, dan R\&D, Bandung: Alfabeta, 2016.

[11] J. W.Creswell, Riset pendidikan, perencanaan, pelaksanaan, dan evaluasi riset kualitatif-kuantitatif edisi kelima, Yogyakarta: Pustaka Timur, 2015.

[12] W. Hendriani, R. Handariyati, and T. M. Sakti, "Penerimaan Keluarga Terhadap Individu yang Mengalami Keterbelakangan Mental," INSAN, vol. 8, no 2, 2006.

[13] M. K. Wardhani, M. S. Rahayu, and D. Rosiana, "Hubungan antara personal adjustment dengan penerimaan terhadap anak berkebutuhan khusus di RSUD X" Prosiding Seminar Nasional Penelitian dan PKM: Sosial, Ekonomi dan Humaniora , pp. 49-54, 2012.

[14] A. Gupta, and N. Singhal, "Positive perceptions of children with disabilities,"Asia Pacific Disability Rehabilitation Journal, vol. 15, pp. 22-35, 2004.

[15] M. Selikowitz, Mengenal Sindroma Down, Jakarta: Arcan, 2001

[16] Kübler-Ross, E. On death and dying: What the dying have to teach doctors, nurses, clergy and their own families, New York: Routledge. 2009.
[17] S. Somantri, Psikologi Anak Luar Biasa, Bandung: Rineka Aditama, 2007.

[18] A. Y. Hamid, Pengalaman keluarga dan nilai anak, 2004

[19] R. S. Wilson, P. A. Boyle, S. R. Levine, L. Yu, S. E. Anagnos, A. S. Buchman, J. A. Schneider, and D. A. Bennett, "Emotional neglect in childhood and cerebral infarction in older age," Neurology, vol. 79, no. 15, pp. 1534-1539, Sep. 2012.

[20] J. D. Ford and E. Russo, "Trauma-focused, present-centered, emotional self-regulation approach to integrated treatment for posttraumatic stress and addiction: Trauma adaptive recover group education and therapy (TARGET)," American Journal of Psychotherapy, vol. 60, pp. 335-355, 2006.

[21] J. D. Ford, "Treatment Implications of Altered Affect Regulation and Information Processing Following Child Maltreatment," Psychiatric Annals, vol. 35, no. 5, pp. 410-419, May 2005.

[22] R. P. Rohner and P. A. Britner, "Worldwide Mental Health Correlates of Parental Acceptance-Rejection: Review of Cross-Cultural and Intracultural Evidence," Cross-Cultural Research, vol. 36, no. 1, pp. 1647, Feb. 2002 